\title{
MAKNA LEKSIKAL PERALATAN TRADISIONAL \\ PRODUKSI BIDANG PERTANIAN SAWAH \\ MASYARAKAT KAILI DI SULAWESI TENGAH
}

\author{
(THE LEXICAL MEANING OF TRADITIONAL \\ PRODUCTION EQUIPMENT OF AGRICULTURE RICE FIELD \\ OF KAILINESE IN CENTRAL SULAWESI)
}

\author{
M. Asri B. \\ Balai Bahasa Sulawesi Tengah \\ Jalan Untad I, BumiRoviga, Tondo, Palu 94118 \\ Telepon (0451) 4705498; 421874 Pos-el: asritoroviga@ymail.com \\ Diterima: 3 Februari 2019; Direvisi: 16 Mei 2019; Disetujui: 18 Juni 2019
}

\begin{abstract}
Abstrak
Penelitian ini adalah penelitian deskriptif yang memuat kajian tentang peralatan tradisonal produksi bidang pertanian sawah. Penelitian ini bertujuan untuk (1) mendeskripsikan makna leksikal peralatan tradisonal produksi bidang pertanian sawah di Kabupaten Sigi dan (2) mendeskripsikan fungsi atau kegunaan peralatan tradisonal bidang pertanian sawah di Kabupaten Sigi. Sumber data penelitian ini adalah peralatan tradisonal bidang pertanian sawah di Kabupaten Sigi. Subjek penelitian ini adalah masyarakat petani sawah suku Kaili yang bertempat tinggal di Kabupaten Sigi. Objek penelitian ini adalah peralatan tradisonal produksi bidang pertanian sawah di Kabupaten Sigi. Data diperoleh melalui observasi, wawancara, dan dokumentasi. Data yang diperoleh dianalisis makna leksikalnya dengan analisis deskriptif. Hasil penelitian ini menunjukkan bahwa secara garis besar, terdapat lima jenis peralatan tradisional produksi pertanian sawah masyarakat Kaili di Sulawesi Tengah dengan fungsi masing-masin, yaitu (1) alat pengolahan tanah, yang memiliki tiga nama alat tradisional, yaitu salaga, pompoe, pomanggi; (2) alat penanaman, yang memiliki tiga nama alat tradisional, yaitu: pohudu, bingga atau rombe, polemba; (3) alat pemeliharaan tanaman, yang memiliki sembilan nama alat tradisional, yaitu: pomanggi, taono, harenggo, popuji, pohive, pandole, huwa, kate, dan povante; (4) alat pemungutan hasil, yang memiliki sembilan nama alat tradisional, yaitu: pula, kato, tali, layo/tonda, gampiri, harenggo, dopipoboba, ompa, dan tap; dan (5) pengolahan hasil, yang memiliki tiga nama alat tradisional, yaitu: nonju patahuda, alu, dan nonjupompeohe.
\end{abstract}

Kata Kunci: masyarakat Kaili, makna leksikal, peralatan tradisional produksi bidang pertanian sawah

\begin{abstract}
This research was descriptive research which contained about study of traditional production equipment of agriculture rice field. This research purposed to (1) describe the lexical meaning of traditional production equipment of agriculture rice field in Sigi Districts and (2) describe function or usability of traditional production equipment of agriculture rice field in Sigi Districts. The data sources of this research were traditional production equipment of agriculture rice field in Sigi Districts. The subject of this research was farm society of Kailinese who lived in Sigi Districts. The object of this research was traditional production
\end{abstract}


equipment of agriculture rice field in Sigi Districts. The data were gotten by observation, interview, and documentation. The data which were found was analyzed its lexical meaning through descriptive analysis. The result of this research showed that in outline there were five kinds of traditional production equipment of agriculture rice field of Kailinese in Central Sulawesi. Its function, that were (1) soil processing equipment which had three names of traditional equipment, that were salaga, pompoe, pomanggi; (2) planter equipment which had three names of traditional equipment, that were pohudu, bingga or rombe, polemba; (3) soil maintenance equipment which had nine names of traditional equipment, that were pomanggi, taono, harenggo, popuji, pohive, pandole, huwa, kate and povante; (4) harvesting equipment which had nine names of traditional equipment, that were pula, kato, tali, layo/tondo, gampiri, harenggo, dopipoboba, ompa, and tap; and (5) result processing equipment which had three names of traditional equipment, that were nonju patahuda, alu, and nonjupompeohe.

Key Words: kailines, lexical meaning, traditional production equipment of agriculture rice field

\section{Pendahuluan}

Daerah Sulawesi Tengah merupakan salah satu daerah di Indonesia yang memiliki banyak suku asli. Terdapat delapan suku asli yang mendiami daerah Sulawesi Tengah, yaitu: (1) Kaili, (2) Pamona, (3) Banggai, (4) Saluan, (5) Buol, (6) Mori, (7) Bungku, dan (8) Balantak. Dari delapan suku asli tersebut, suku Kaili merupakan suku yang terbesar populasi dan pesebarannya.

Suku Kaili tersebar mendiami sebagian besar dari Provinsi Sulawesi Tengah, khususnya wilayah Kabupaten Donggala, Kabupaten Sigi, dan Kota Palu, di seluruh daerah di lembah antara Gunung Gawalise, Gunung Nokilalaki, Kulawi, dan Gunung Raranggonau. Mereka juga menghuni wilayah pantai timur Sulawesi Tengah, meliputi Kabupaten ParigiMoutong, Kabupaten Tojo Una Una, dan
Kabupaten Poso. Masyarakat suku Kaili mendiami kampung/desa di Teluk Tomini, yaitu Tinombo, Moutong, Parigi, Sausu, Ampana, Tojo dan Una Una. Di Kabupaten Poso, mereka mendiami daerah Mapane, Uekuli, dan pesisir Pantai Poso.

Suku Kaili adalah suku agraris. Artinya, mata pencaharian mereka sebagian besar adalah petani yang bercocok tanam di sawah dan ladang. Di samping itu, masyarakat suku Kaili yang tinggal di dataran tinggi mengambil hasil bumi di hutan, seperti rotan, damar, kemiri, dan beternak. Adapun masyarakat suku Kaili yang di pesisir pantai, di samping bertani dan berkebun, mereka juga hidup sebagai nelayan dan berdagang antarpulau ke Kalimantan. Makanan asli suku Kaili pada umumnya adalah nasi karena sebagian besar tanah dataran di lembah Palu, Parigi sampai ke Poso merupakan daerah persawahan. 
Berkaitan dengan istilah pertanian sawah dan pembudidayaannya, dalam Kamus Besar Bahasa Indonesia (2008: 1140) dijelaskan bahwa pertanian adalah perihal bertani, mengusahakan tanah dengan tanam-menanam atau segala yang bertalian dengan tanam-menanam (pengusahaan tanah). Dalam kamus besar tersebut, kata sawah adalah tanah yang digarap dan diairi untuk tempat menanam padi. Jadi, pertanian sawah adalah pengusahaan tanah dengan tanam-menanam tumbuhan yang menghasilkan padi. Pelaksanaan budidaya padi sawah harus melalui beberapa tahapan, salah satunya adalah tahapan pengolaha lahan. Tahapan pengolahan lahan menurut Pitojo (2000:26) adalah sebagai berikut: (1) pembersihan gelengan dan saluran atau parit; (2) pencangkulan sudut petakan; dan (3) pembajakan dan penggaruan.

Sebagai daerah agraris yang mata pencahariannya di sektor pertanian lebih dominan, peralatan produksi, khususnya peralatan tradisional banyak dimiliki oleh suku Kaili tersebut. Kaitannya dengan istilah peralatan tradisional, Herawati dan Sumintarsih, (1989:2) menjelaskan bahwa peralatan tradisional adalah seperangkat alat yang masih sederhana sifatnya, yang digunakan oleh sekelompok masyarakat secara turun-temurun dan merupakan bagian dari sistem teknologi yang mereka miliki menurut konsepsi kebudayaannya. Dalam penggunaan peralatan tradisional, manusia memegang peranan penting sebagai penggerak atau tenaga utama. Peralatan yang digunakan untuk menunjang proses pertanian padi banyak macamnya, yaitu peralatan yang dipakai ketika prapenanaman, penanaman, pemeliharaan tanaman, pemanenan, dan pengolahan hasil panen.

Terdapat beberapa alat pertanian tradisioanl yang digunakan oleh nenek moyang suku Kaili sebelum masa modernisasi alat pertanian, seperti salaga, pompoe, pomanggi, pohudu, bingga atau rombe, dan polemba. Peralatan-peralatan tradisional tersebut, sampai pada era tahun 1990-an masih dipergunakan. Masyarakat tani suku Kaili masih menggunakan alat-alat tradisional, seperti parang, dijadikan alat untuk memotong rumput yang berada di sawah; cangkul untuk mebersihkan rumput juga; dan ani-ani, alat untuk memotong padi. Dalam proses pengolahan sawah tradisonal, masyarakat masih menggunakan sapi atau kerbau sebagai alat untuk mengolah sawah dan ladang mereka. Alat-alat yang digunakan dalam proses pengolahan sawah tradional seperti pompoe, pomanggi, pohudu, bingga atau rombe, dan polemba. Untuk mengolah hasil gabah kering, mereka membanting padi atau gabah yang baru dipotong, sehingga menjadi padi. Setelah menjadi padi, mereka mengolahnya kembali 
menjadi beras dengan cara dipukul ke lesung sehingga menjadi beras. Masyarakat tani dulunya menanam padi dengan cara bergotong royong.

Setelah memasuki era tahun 2000-an, peralatan tradisional pertanian, termasuk alat-alat produksi pertanian sudah mulai tergantikan oleh alat-alat teknologi pertanian. Masyarakat Kaili sudah beralih ke teknologi pertanian, seperti traktor sebagai pengganti sapi/kerbau untuk menggarap lahan pertanian mereka, mesin deros untuk mengolah gabah kering yang baru dipotong, mesin penggiling padi sebagai alat untuk mengolah padi menjadi beras. Penghasilan masyarakat tani setelah menggunakan teknologi pertanian lebih meningkat.

Permasalahan yang muncul adalah pola kehidupan masyarakat selalu terus berkembang sejalan dengan era pembagunan yang terus menerus dikembangkan dan dilaksanakan. Teknologi modern sedikit demi sedikit menggeser peranan teknologi tradisional. Alat-alat tradisioanl produksi pertanian sawah yang digunakan oleh suku Kaili seperti salaga, pompoe, pomanggi, pohudu, bingga atau rombe, dan polemba kini tinggal kenangan. Keberadaannya sudah tergantikan dengan alat-alat canggih dan modern. Kenyataan ini tidak dapat kita hindari karena adanya dorongan keinginan masyarakat yang selalu menggalakkan perekonomian, baik dari segi bahan, kualitas maupun kuantitasnya yang berujung pada peningkatan hasil produksi dan peningkatan taraf kehidupan masyarakat.

Dari latar belakang yang telah diuraikan tersebut, penelitian ini akan membahas peralatan tradisional produksi bidang pertanian sawah, khususnya sawah di Kabupaten Sigi yang sekaligus menjadi lokasi penelitian. Peralatan tradional produksi bidang pertanian sawah yang ada akan didata, dijabarkan makna leksikalnya, dan fungsi atau kegunaan alat-alat tersebut. Penelitian ini dibuat dengan harapan agar dapat dipergunakan sebagai bahan dokumentasi terhadap nama-nama/istilah peralatan tradisioanal pertanian sawah suku Kaili yang sekarang sudah tergantikan dengan alat-alat produksi pertanian modern.

\section{Landasan Teori}

\subsection{Semantik}

Semantik di dalam bahasa Indonesia berasal dari bahasa Inggris semantics, dari bahasa Yunani sema (nomina) 'tanda' atau dari verba samaino 'menandai'. Istilah semantik digunakan oleh para pakar bahasa untuk menyebut bagian ilmu bahasa yang mempelajari makna. Semantik merupakan bagian dari tiga tataran bahasa yang meliputi fonologi, tata bahasa (morfologi-sintaksis), dan semantik (Djajasudarma, 1999:1). 
Kata semantik sebenarnya merupakan istilah teknis yang mengandung pengertian studi tentang makna. Ini berarti bahwa objek semantik adalah makna. Semantik memfokuskan kajian pada makna-makna suatu kata atau bahasa (Pateda 1989:15). Parera (2004:42) juga mengungkapkan hal senada mengenai semantik, bahwa semantik merupakan satu cabang studi linguistik general. Selanjutnya, secara sederhana, istilah semantik adalah cabang ilmu linguistik yang membahas tentang arti atau makna. Contoh jelas dari perilaku atau deskripsi semantik adalah leksikografi. Masing-masing leksem diberi perian artinya atau maknanya (Verhaar, 2012: 13). Dari beberapa terori tersebut, disimpulkan bahwa semantik adalah suatu studi dan analisis tentang makna-makna bahasa secara umum.

\subsection{Makna}

Berbicara tentang makna tentunya kita tidak bisa lepas dari kamus. Kamus merupakan panduan utama masyarakat untuk memberikan makna pada suatu bahasa atau kata. Meskipun demikian, perlu dipahami bahwa makna yang dijelaskan dalam kamus hanyalah makna leksikal.

Teori-teori yang membicarakan tentang makna sangat beragam. Grice \& Bolinger dalam (Aminudin 2001:53) menjelaskan bahwa makna adalah hubungan antara bahasa dengan dunia luar yang telah disepakati bersama oleh para pemakai bahasa sehingga dapat saling dimengerti. Pendapat itu senada dengan teori Wijana \& Rohmadi (2008:11) yang menyatakan bahwa makna adalah konsep abstrak pengalaman manusia, tetapi bukanlah pengalaman orang per orang. Bila makna merupakan pengalaman orang per orang, setiap kata akan memiliki berbagai macam makna karena pengalaman individu yang satu dengan yang lain berbeda-beda, tidak mungkin sama.

Hal yang sama diungkapkan oleh Djajasudarma (1999:5), bahwa makna adalah pertautan yang ada di antara unsurunsur bahasa itu sendiri (terutama katakata). Makna sebagai penghubung bahasa dengan dunia luar sesuai dengan kesepakatan para pemakainya sehingga dapat saling mengerti. Berkaitan dengan itu, makna memiliki tiga tingkat keberadaan, yakni:

(1) pada tingkat pertama, makna menjadi isi dari suatu bentuk kebahasaan;

(2) pada tingkat kedua, makna menjadi isi dari suatu kebahasaan; dan

(3) pada tingkat ketiga, makna menjadi isi komunikasi yang mampu membuahkan informasi tertentu.

Dari pendapat-pendapat tersebut, dapat kita simpulkan bahwa makna merupakan sesuatu yang terkandung dalam kata atau bahasa yang disepakati pengguna 
bahasa tersebut sehingga kata atau bahasa itu dapat digunakan untuk berkomunikasi dan saling memahami.

\subsection{Jenis Makna}

Dalam berbagai kepustakaan, disebutkan berbagai nama atau istilah jenis makna. Agar tidak terlalu terlibat dalam berbagai nama dengan istilah-istilah itu, pengategorian jenis makna ini difokuskan pada pendapat Chaer (2006:117-128) yang membagi jenis makna atas (1) makna leksikal, (2) makna gramatikal, (3) makna kontekstual, (4) makana idiomatikal, dan (5) makna konotasi. Kelima jenis makna tersebut akan diuraikan satu per satu.

\subsubsection{Makna Leksikal}

Kata leksikal adalah bentuk adjektiva dari kata leksikon. Maka, secara harfiah, makna leksikal berarti makna yang bersifat leksikon. Namun, yang dimaksud sebenarnya makna leksikal adalah makna secara inheren yang dimiliki oleh setiap leksem (sebagai satuan leksikon). Jika leksem itu kita samakan konsepnya dengan kata, leksikal berarti sama dengan kata.

Makna kata atu makna leksikal adalah makna yang secara inheren ada di dalam kata itu, terlepas dari konteks apapun. Misalnya, kata pensil memiliki makna sejenis alat tulis yang terbuat dari kayu dan arang. Merujuk dari hal itu, makna leksikal dapat kita katakan makna apa adanya, makna yang sesuai dengan hasil observasi, makna yang sesuai dengan rujukannya, dan makna yang sesuai dengan konsepnya. Oleh karena itu, apa yang disebut makna leksikal ini sama dengan yang disebut makna konseptual, makna denotatif, dan makna referensial. Senada dengan hal itu, Kridalaksana (2001:133) menyatakan bahwa makna leksikal adalah makna unsurunsur bahasa sebagai lambang benda, peristiwa, dan lain-lain. Makna leksikal ini mempunyai unsur-unsur bahasa yang terlepas dari penggunaannya atau konteksnya.

\subsubsection{Makna Gramatikal}

Makna gramatikal lazim dipertentangkan dengan makna leksikal. Makna gramatikal adalah makna yang terjadi sebagai hasil proses gramatikal. Proses gramatikal dalam hal ini meliputi afiksasi, reduplikasi, komposisi atau fraseologi, dan proses pengalimatan. Kridalaksana $\quad(2001: 132) \quad$ juga mengemukakan pendapatnya bahwa makna gramatikal adalah hubungan antara unsurunsur bahasa dalam satuan-satuan yang lebih besar. Misalnya, hubungan antara kata dengan kata lain dalam frasa atau klausa.

\subsubsection{Makna Kontekstual}

Dalam pertuturan sehari-hari, kita jarang sekali menggunakan kata-kata dalam makna leksikalnya ataupun makna gramatikalnya. Kita lebih banyak menggunakan kata-kata itu dalam makna 
konteksnya. Oleh karena itu, sebuah kata baru jelas maknanya setelah kata itu berada dalam konteksnya. Misalnya, kata jatuh dalam kalimat "Dia jatuh dalam ujian." atau Lebaran tahun ini jatuh pada tanggal 26 Juni." Kata jatuh pada kedua contoh kalimat itu bukanlah makna leksikal, melainkan dalam makna konteksnya.

Dalam penjelasan ini, Chaer (2006:120) menjelaskan dengan rinci bahwa konteks dapat dibagi menjadi berapa bagian, yaitu konteks linguistik, konteks situasi (tempat dan waktu), konteks bidang kegiatan atau keilmuan, bidang sosial dan budaya, atau konteks lainnya. Senada dengan itu, Kridalaksana (2001:133) menambahkan bahwa makna kontekstual adalah hubungan antara ujaran dan situasi di mana ujaran itu dipakai.

\subsubsection{Makna Idiomatikal}

Untuk memahami apa yang disebut makna idiomatikal, perlu dijelaskan apa yang disebut idiom. Dalam berbagai kepustakaan, idiom lazim dijelaskan sebagai satuan bahasa, baik berupa kata maupun gabungan kata yang maknanya tidak dapat ditelusuri secara leksikal maupun gramatikal. Misalnya, konfik ke-an dengan dasar adjektiva pada kata keberanian, kekuatan, dan kemewahan bermakna gramatikal 'hal'. Bandingkan dengan kata kemaluan yang kategorinya sama tapi bukan bermakna hal malu, melainkan bermakna alat kelamin, ini bermakna idiomatik. Bentuk gabungan kata seperti membanting tulang, memeras keringat, dan meja hijau juga bermakna idiomatikal.

\subsubsection{Makna Konotasi}

Konsep konotasi atau konotatif berkaitan dengan nilai rasa kata. Hal itu diungkap oleh Arifin dan Tasai (2008:29) yang menjelaskan bahwa makna konotatif adalah makna asosiatif, makna yang timbul akibat dari sikap sosial, sikap pribadi, dan kriteria tambahan yang dikenakan pada sebuah makna konseptual. Kata makan dalam makna konotatif dapat berarti untung atau pukul. Makna konotasi atau konotatif sifatnya lebih profesional dan oprasional daripada makna denotasi. Makna konotatif adalah makna yang dikaitkan dengan suatu kondisi dan situasi tertentu. Makna konotatif lebih bersifat pribadi atau khusus, sedangkan makna denotatif lebih bersifat umum.

\section{Metode Penelitian}

Penelitian ini adalah penelitian deskriptif, yaitu penelitian yang mendeskripsikan nama-nama peralatan produksi pertanian sawah masyarakat Kaili di Sulawesi Tengah, khususnya di Kabupaten Sigi, berdasarkan makna leksikalnya. Penelitian yang dilakukan semata-mata berdasarkan pada fakta yang ada atau fenomena yang secara empiris hidup pada penutur-penuturnya, sehingga 
yang dihasilkan atau dicatat berupa perian bahasa yang biasa dikatakan sifatnya, seperti potret, paparan seperti adanya (Sudaryanto, 1998:63). Data yang diperoleh berupa deskripsi, yaitu uraian objektif mengenai nama-nama, makna leksikal dan fungsi peralatan pertanian sawah yang dulunya benar-benar digunakan oleh petani sawah bagi suku Kaili di Sulawesi Tengah, khususnya di Kabupaten Sigi.

Pengumpulan data pada penelitian ini dilakukan dengan tiga tahap, yaitu observasi, wawancara, dan dokumentasi. Dengan observasi, peneliti mengamati secara langsung daerah yang menjadi penelitian. Peneliti mengamati dan mendengarkan keterangan dan informasi dari penduduk petani sawah setempat.

Dengan wawancara, peneliti mewawancarai warga asli Kabupaten Sigi, khususnya yang berprofesi sebagai petani. Wawancara dilakukan dengan tujuan untuk memperoleh data yang sah dan akurat. Oleh karena itu, warga yang diwawancarai adalah orang yang sudah lama berprofesi sebagai petani sawah, supaya data lebih akurat.

Dokumentasi dalam penelitian ini merupakan pengumpulan data melalui dokumen-dokumen yang ada, berupa catatan-catatan masyarakat tani setempat atau foto/gambar alat pertanian. Dukungan dokumentasi juga dari buku-buku laporan hasil penelitian sebelumnya. Tentunya, hasil penelitian yang relevan dengan judul penelitian ini.

Teknik pengolahan data dilakukan dengan cara data yang diperoleh secara lisan dan tulisan yang berupa nama-nama peralatan pertanian sawah dipilah-pilah berdasarkan jenisnya. Setelah data dipilahpilah, kemudian dilakukan reduksi data, yaitu membuang data yang dianggap tidak relevan dalam peralatan pertanian sawah. Data yang relevan dianalisis dari segi semantis, yaitu berdasarkan makna leksikalnya. Setelah itu, data dijabarkan berdasarkan fungsi atau kegunaan alat-alat tersebut.

\section{Hasil dan Pembahasan}

Penelitian tentang Makna Leksikal Peralatan Tradisional Produksi Bidang Pertanian Sawah Masyarakat Kaili di Sulawesi Tengah dilaksanakan di Kabupaten Sigi. Hasil penelitian ini berupa data macam-macam peralatan tradisional pertanian yang digunakan di sawah di Kabupaten Sigi serta pendeskripsian makna leksikalnya. Dalam penelitian ini, didapatkan juga hasil yang berupa fungsi atau kegunaan peralatan tradisional pertanian tersebut. Peralatan-peralatan tradisional pertanian tersebut digunakan oleh masyarakat dengan tujuan mencapai hasil produksi yang maksimal. Alat produksi pertanian ini dibagi atas beberapa bagian, 
yaitu (1) alat pengolahan tanah, (2) alat penanaman, (3) alat pemeliharaan tanaman, (4) alat pemungutan hasil, dan (5) pengolahan hasil.

\subsection{Alat Pengolahan Tanah}

Ada beberapa alat tradisional yang digunakan oleh masyarakat Kaili di daerah Sulawesi Tengah untuk mengolah tanah pertaniannya sebelum ditanami padi, di antaranya: (a) salaga, (b) pompoe, (c) pomanggi (pacul). Sebelum ketiga alat ini digunakan, terlebih dahulu tanah atau lahan diolah dengan sistem peurujak.
Sistem peurujak yaitu suatu proses awal pengolahan tanah dengan cara menghancurkan tanah dengan menghalau sejumlah kerbau oleh beberapa orang. Sejumlah kerbau dilepaskan di sawah. Pada setiap sisi sawah, dijaga oleh orang yang senantiasa berteriak dan memberi aba-aba agar kerbau secara terus menerus berjalan pada luas tanah yang dihendaki. Setelah perujak selesai dilakukan, barulah difungsikan ketiga alat pengolah tanah tersebut.

Tabel 1: Alat Pengolah Tanah

\begin{tabular}{|r|l|l|l|}
\hline No. & \multicolumn{1}{|c|}{ Nama Alat dan Artinya } & \multicolumn{1}{c|}{ Fungsi/Kegunaan } & \multicolumn{1}{c|}{ Keterangan } \\
\hline 1. & $\begin{array}{l}\text { Salaga adalah jenis alat } \\
\text { perata dan penyisir tanah } \\
\text { yang terbuat dari besi } \\
\text { kayu dan tali. Salaga } \\
\text { ditarik oleh dua ekor } \\
\text { kerbau /sapi. }\end{array}$ & $\begin{array}{l}\text { Untuk menyisir tanah } \\
\text { atau meratakan tanah }\end{array}$ & $\begin{array}{l}\text { Alat ini dijalankan atau } \\
\text { dikendalikan oleh tenaga } \\
\text { laki-laki. }\end{array}$ \\
\hline 2. & $\begin{array}{l}\text { Pompoe adalah alat yang } \\
\text { digunakan untuk } \\
\text { menghaluskan dan lebih } \\
\text { meratakan lagi tanah yang } \\
\text { sudah di-salaga. Pompoe } \\
\text { ditarik oleh dua ekor } \\
\text { kerbau/sapi, terbuat dari } \\
\text { kayu dan sejumlah tali. } \\
\text { Salaga alat penghancur } \\
\text { dan penyisir tanah yang } \\
\text { berbentuk sisir, sedangkan } \\
\text { pompoe alat penghalus dan } \\
\text { perata tanah dari papan } \\
\text { yang rata. Papan yang } \\
\text { berposisi berdiri agak } \\
\text { miring ini berfungsi } \\
\text { meghaluskan dan } \\
\text { meratakan tanah jika } \\
\text { digerakkan ke depan. }\end{array}$ & $\begin{array}{l}\text { Untuk lebih } \\
\text { menghaluskan dan lebih }\end{array}$ & $\begin{array}{l}\text { Alat ini dijalankan atau } \\
\text { dikendalikan oleh tenaga } \\
\text { laki-laki }\end{array}$ \\
\hline 3omanggi (pacul) adalah & Untuk mencangkul dan & Alat ini bisa digunakan \\
\hline
\end{tabular}




\begin{tabular}{|l|l|l|l|}
\hline $\begin{array}{l}\text { alat yang digunakan untuk } \\
\text { mencangkul bagian-bagian } \\
\text { sudut petak sawah dan } \\
\text { pembuatan pematang. } \\
\text { Mata pomanggi biasanya } \\
\text { terbuat dari besi dan } \\
\text { tangkainya terbuat dari } \\
\text { kayu dan bambu. }\end{array}$ & $\begin{array}{l}\text { membuat pematang } \\
\text { sawah. }\end{array}$ & \\
perempuan
\end{tabular}

\subsection{Alat Penanaman}

Penanaman padi dimulai dari masa pembibitan sampai pemindahan/ penanaman bibit padi setelah mencapai umur tertentu. Tanah yang sudah dipersiapkan untuk persemaian bibit padi terlebih dahulu dikerjakan dengan mempergunakan salaga, pompoe, dan pomanggi. Setelah tanah menjadi rata, pada tahap akhir, tanah diratakan dan dihaluskan lagi agar benarbenar siap untuk ditaburi bibit padi.

Sama halnya dengan proses pengolahan tanah, terdapat beberapa alat tradisioanl yang digunkan oleh masyarakat Kaili dalam proses penanaman padi, di antaranya: (a) pohudu, (b) bingga atau rombe, dan (c) polemba (alat pemikul).

Tabel 2: Alat Penanaman

\begin{tabular}{|c|c|c|c|}
\hline No. & Nama Alat dan Artinya & Fungsi/Kegunaan & Keterangan \\
\hline 1. & $\begin{array}{l}\text { Pohudu adalah alat yang } \\
\text { digunakan untuk menghaluskan } \\
\text { tanah yang sudah diratakan agar } \\
\text { tanah bebar-benar siap untuk } \\
\text { ditanami atau ditaburi bibit padi. } \\
\text { Semula, pahudu hanya terbuat } \\
\text { dari selembar papan atau } \\
\text { potongan bambu dan langsung } \\
\text { dipegang tangan. Dengan cara } \\
\text { berjongkok, seorang laki-laki } \\
\text { meratakan tanah pembibitan } \\
\text { secara gerak mundur. } \\
\text { Kini, pohudu disempurnakan } \\
\text { dengan cara memasang tangkai } \\
\text { pada selembar papan sehingga } \\
\text { cara penggunaannya sambil } \\
\text { berdiri dan bisa digerakkan ke } \\
\text { depan dan ke belakang dengan } \\
\text { cara mendorong dan menariknya. }\end{array}$ & $\begin{array}{l}\text { Untuk lebih } \\
\text { menghaluskan tanah } \\
\text { yang sudah diratakan. }\end{array}$ & $\begin{array}{l}\text { Alat ini dijalankan } \\
\text { atau dikendalikan } \\
\text { oleh tenaga laki- } \\
\text { laki. }\end{array}$ \\
\hline
\end{tabular}




\begin{tabular}{|l|l|l|l|}
\hline 2. & $\begin{array}{l}\text { Binggaatau Rombe adalah tempat } \\
\text { atau wadah bibit padi yang akan } \\
\text { ditaburkan. Baik bingga atau } \\
\text { rombe, keduanya terbuat dari } \\
\text { anyaman daun silar (jenis palem). } \\
\text { Bingga berbentuk bakul yang } \\
\text { dibuat dari irisan daun silar dan } \\
\text { anyamannya lebih kasar. Rombe } \\
\text { berbentuk seperti kantong irisan } \\
\text { dan anyamannya lebih halus. } \\
\text { Keduanya, baik bingga maupun } \\
\text { rombe dilengkapi tali } \\
\text { penggantung sehingga mudah } \\
\text { digantungkan jika disimpan atau } \\
\text { dibawa sebagai tempat } \\
\text { pengusung. }\end{array}$ & $\begin{array}{l}\text { Bisa digunakan } \\
\text { oleh laki-laki dan } \\
\text { perempuan. }\end{array}$ \\
\hline 3. & $\begin{array}{l}\text { Polemba adalah alat yang } \\
\text { digunakan untuk memikul dan } \\
\text { membawa bingga atau rombe ke } \\
\text { tempat persemaian. Polemba } \\
\text { biasanya terbuat dari kayu atau } \\
\text { bambu. }\end{array}$ & $\begin{array}{l}\text { Untuk memikul } \\
\text { bingga atau rombe ke } \\
\text { tempat persemaian. }\end{array}$ & $\begin{array}{l}\text { Bisa digunakan } \\
\text { oleh laki-laki dan } \\
\text { perempuan. } \\
\text {. }\end{array}$ \\
\hline
\end{tabular}

\subsection{Alat Pemeliharaan Tanaman}

Pada dasarnya, pemeliharaan padi sawah hanya dibedakan atas dua macam, yaitu (1) pemeliharaan dengan cara pembersihan rumput dan (2) pemberantasan berbagai jenis hama. Alat pembersih rumput tradisioanl terdiri atas (1) pomanggi, (2) taono, dan (3) harenggo. Selanjutnya, jenis alat pemeliharaan, terutama alat yang digunakan untuk memberantas berbagai hama tanaman padi sawah di antaranya (1) popuji, (2) pohive, (3) pandole, (4) huwa, (5) kate, dan (6) povante.

Tabel 3: Alat Pemeliharaan Tanaman

\begin{tabular}{|c|l|l|l|}
\hline No. & \multicolumn{1}{|c|}{ Nama Alat dan Artinya } & \multicolumn{1}{|c|}{ Fungsi/Kegunaan } & \multicolumn{1}{|c|}{ Keterangan } \\
\hline 1. & $\begin{array}{l}\text { Pomanggi atau pacul adalah alat } \\
\text { tradisional yang digunakan untuk } \\
\text { membersihkan tanaman padi dari } \\
\text { rumput yang tumbuh di saluran } \\
\text { air. Bahan dasarnya terbuat dari } \\
\text { besi dan pemegangnya atau } \\
\text { gagangnya terbuat dari kayu. }\end{array}$ & $\begin{array}{l}\text { Untuk membersikan } \\
\text { rumput di saluran air. }\end{array}$ & $\begin{array}{l}\text { Alat ini digunakan } \\
\text { oleh tenaga laki- } \\
\text { laki. }\end{array}$ \\
\hline 2. & $\begin{array}{l}\text { Taono atau parang adalah alat } \\
\text { tradisional yang digunakan untuk } \\
\text { membersihkan tanaman padi dari } \\
\text { rumput yang tumbuh di pematang }\end{array}$ & $\begin{array}{l}\text { Untuk membersikan } \\
\text { rumput di pematang } \\
\text { sawah. }\end{array}$ & $\begin{array}{l}\text { Alat ini digunakan } \\
\text { oleh tenaga laki- } \\
\text { laki. }\end{array}$ \\
\hline
\end{tabular}




\begin{tabular}{|c|c|c|c|}
\hline & $\begin{array}{l}\text { sawah. Bahan dasarnya terbuat } \\
\text { dari besi dan pemegangnya atau } \\
\text { gagangnya terbuat dari kayu }\end{array}$ & & \\
\hline 3. & $\begin{array}{l}\text { Harenggo atau sabit adalah alat } \\
\text { tradisional yang digunakan untuk } \\
\text { membersihkan tanaman padi dari } \\
\text { rumput yang tumbuh di pematang } \\
\text { sawah. Bahan dasarnya terbuat } \\
\text { dari besi dan pemegannya atau } \\
\text { gagangnya terbuat dari kayu }\end{array}$ & $\begin{array}{l}\text { Untuk membersikan } \\
\text { rumput di pematang } \\
\text { sawah. }\end{array}$ & $\begin{array}{l}\text { Alat ini digunakan } \\
\text { oleh tenaga laki- } \\
\text { laki. }\end{array}$ \\
\hline 4. & $\begin{array}{l}\text { Popuji adalah alat pembersih } \\
\text { hama tanaman padi yang terbuat } \\
\text { dari bambu bulat dan kayu yang } \\
\text { dibentuk seperti pompa tangan. } \\
\text { Adapun cara pemakaiannya, } \\
\text { apabila popuji ditarik berfungsi } \\
\text { menghisap cairan obat-obatan dan } \\
\text { bila didorong ke depan akan } \\
\text { menyemprotkan cairan obat- } \\
\text { obatan. }\end{array}$ & $\begin{array}{l}\text { Sebagi alat } \\
\text { penyemprot cairan } \\
\text { obat-obatan untuk } \\
\text { disemprotkan ke } \\
\text { tanaman padi. }\end{array}$ & $\begin{array}{l}\text { Alat ini digunakan } \\
\text { oleh tenaga laki- } \\
\text { laki. }\end{array}$ \\
\hline 5 . & $\begin{array}{l}\text { pohive adalah alat pembersih } \\
\text { hama tanaman padi yang terbuat } \\
\text { dari batang padi atau rumput } \\
\text { alang-alang yang diikat dengan } \\
\text { tali. Cara kerjanya, pohive } \\
\text { dicelupkan ke cairan obat-obatan } \\
\text { kemudian dipercikkan ke arah } \\
\text { tanaman padi secara menyeluruh. }\end{array}$ & $\begin{array}{l}\text { Untuk memercikkan } \\
\text { cairan obat-obatan ke } \\
\text { tanaman padi. }\end{array}$ & $\begin{array}{l}\text { Alat ini digunakan } \\
\text { oleh tenaga laki- } \\
\text { laki. }\end{array}$ \\
\hline 6. & $\begin{array}{l}\text { Pandole atau linggis adalah alat } \\
\text { pembersih hama tanaman padi } \\
\text { yang seluruh bahannya terbuat } \\
\text { besi. Memburu tikus dengan alat } \\
\text { ini dilakukan dengan cara } \\
\text { menggali lubang-lubang tikus } \\
\text { dan dipasangkan dengan alat } \\
\text { bantu bambu bulat yang satu } \\
\text { bagian ujungnya berlubang dan } \\
\text { ujung yang lain masih tertutup } \\
\text { ruas. Dengan cara demikian, tikus } \\
\text { akan terpaksa masuk ke dalam } \\
\text { lubang tabung bambu, tinggal } \\
\text { ditangkap dan dibunuh. }\end{array}$ & $\begin{array}{l}\text { Sebagai alat penggali } \\
\text { tanah (lubang-lubang } \\
\text { tikus pada tanah). }\end{array}$ & $\begin{array}{l}\text { Dilakukan secara } \\
\text { beramai-ramai } \\
\text { oleh laki-laki } \\
\text { maupun perempun } \\
\text { dan orang dewasa } \\
\text { maupun anak-anak. }\end{array}$ \\
\hline 7. & $\begin{array}{l}\text { Huwa adalah sejenis linggis yang } \\
\text { terbuat dari tangkai kayu bulat } \\
\text { dan bagian runcingnya atau } \\
\text { ujungnya terbuat dari besi. }\end{array}$ & $\begin{array}{l}\text { Untuk memburu tikus- } \\
\text { tikus dengan cara } \\
\text { menggali lubang } \\
\text { tempat persembunyian } \\
\text { tikus. }\end{array}$ & $\begin{array}{l}\text { Dilakukan secara } \\
\text { beramai-ramai } \\
\text { oleh laki-laki } \\
\text { maupun perempun, } \\
\text { orang dewasa } \\
\text { maupun anak-anak }\end{array}$ \\
\hline 8. & Kate adalah alat untuk mengusir & Untuk mengusir hama & dapat \\
\hline
\end{tabular}




\begin{tabular}{|c|c|c|c|}
\hline & $\begin{array}{l}\text { burung-burung pemakan buah } \\
\text { padi. Kate terbuat dari tiang } \\
\text { bambu/kayu, tali dan sejenis } \\
\text { kaleng-kaleng yang dilengkapi } \\
\text { dengan sejenis benda pemukul } \\
\text { agar kaleng berbunyi jika } \\
\text { digoyang. Jika tali sentralnya } \\
\text { digoyang, seluruh tali akan } \\
\text { bergoyang sehingga kaleng- } \\
\text { kaleng yang digantungkan } \\
\text { mengeluarkan bunyi-bunyian } \\
\text { yang menyebabkan burung- } \\
\text { burung pemakan buah padi akan } \\
\text { terusir terbang meninggalkan } \\
\text { buah padi. }\end{array}$ & $\begin{array}{l}\text { pemakan buah padi } \\
\text { (burun-burung). }\end{array}$ & $\begin{array}{l}\text { digunakan oleh } \\
\text { laki-laki maupun } \\
\text { perempuan, dewasa } \\
\text { maupun anak-anak. }\end{array}$ \\
\hline 9. & $\begin{array}{l}\text { Povante adalah alat untuk } \\
\text { mengusir burung-burung pemakan } \\
\text { padi yang terbuat dari tiang } \\
\text { kayu/bambu, tali, dan kain-kain } \\
\text { tua/bekas. Tiang-tiang poventa } \\
\text { didirikan di pematang -pematang } \\
\text { sawah, dihubungkan dengan tali } \\
\text { dan digantungkan dengan kain- } \\
\text { kain bekas. Alat ini jika tertiup } \\
\text { angin akan bergoyang menyerupai } \\
\text { gerak manusia. Kain-kain tersebut } \\
\text { sering dibentuk seperti manusia } \\
\text { berdiri sehingga burung-burung } \\
\text { pemakan padi merasa takut dan } \\
\text { terbang meninggalkan buah padi. }\end{array}$ & $\begin{array}{l}\text { Untuk mengusir hama } \\
\text { pemakan buah padi } \\
\text { (burun-burung). }\end{array}$ & $\begin{array}{l}\text { Alat ini dapat } \\
\text { digunakan oleh } \\
\text { laki-laki maupun } \\
\text { perempuan, dewasa } \\
\text { maupun anak-anak }\end{array}$ \\
\hline
\end{tabular}

\subsection{Alat Pemungutan Hasil}

Untuk memungut hasil pertenian pada sawah, mulai dari pemetikan sampai penyimpanan, dapat digunakan berbagai macam alat sebagai berikut (1) pula, (2) kato, (3) tali, (4) layo/tonda, (5) gampiri, (6) harenggo, (7) dopi poboba, (8) ompa, dan (9) tapi.

Tabel 4: Alat Pemungutan Hasil

\begin{tabular}{|c|c|c|c|}
\hline No. & Nama Alat dan Artinya & Fungsi/Kegunaan & Keterangan \\
\hline 1. & $\begin{array}{l}\text { Pula adalah sejenis ketam/ani-ani } \\
\text { yang dibuat secara sederhana dari } \\
\text { bahan besi tipis dan tajam sebagai } \\
\text { matanya yang diletakkan pada } \\
\text { kayu lunak. Cara pemakaiannya, } \\
\text { pula dijepit antara dua jari-jari } \\
\text { tengah. Tangkai padi akan teralas } \\
\text { di mata pula yang tajam sehinga } \\
\text { tangkai padi akan putus terpotong. }\end{array}$ & $\begin{array}{l}\text { Untuk memotong } \\
\text { tangkai padi dari } \\
\text { batangnya. }\end{array}$ & $\begin{array}{l}\text { Alat ini digunakan } \\
\text { oleh tenaga } \\
\text { perempuan. }\end{array}$ \\
\hline
\end{tabular}




\begin{tabular}{|c|c|c|c|}
\hline 2. & $\begin{array}{l}\text { Kato adalah sejenis ketam/ani-ani, } \\
\text { akan tetapi cara pembuatannya } \\
\text { sudah lebih disempurnakan. } \\
\text { Bahannya terbuat dari bambu } \\
\text { bulat, papan tipis,dan besi tajam } \\
\text { tipis sebagai matanya. Bambu } \\
\text { bulat yang berukuran sedang } \\
\text { dipasang pada papan tipis } \\
\text { melintang untuk meletakkan besi } \\
\text { tipis dan tajam sebagai mata kato. } \\
\text { Cara pemakaiannya, kato dijepit } \\
\text { di antara jari tangan. }\end{array}$ & $\begin{array}{l}\text { Untuk memotong } \\
\text { tangkai padi dari } \\
\text { batangnya. }\end{array}$ & $\begin{array}{l}\text { Alat ini digunakan } \\
\text { oleh tenaga } \\
\text { perempuan. }\end{array}$ \\
\hline 3. & $\begin{array}{l}\text { Tali adalah alat untuk mengikat } \\
\text { padi yang telah selesai dituai yang } \\
\text { terbuat dari rautan daun silar. Tali } \\
\text { diikatkan pada tangkai padi } \\
\text { setelah mencapai jumlah tertentu } \\
\text { dalam gengaman para penuainya. }\end{array}$ & Untuk mengikat padi & $\begin{array}{l}\text { Alat ini digunakan } \\
\text { oleh tenaga } \\
\text { perempuan. }\end{array}$ \\
\hline 4. & $\begin{array}{l}\text { Layo/tonda adalah suatu wadah } \\
\text { sejenis kantong yang terbuat dari } \\
\text { rautan silar atau rautan bambu } \\
\text { yang dianyam dan dilengkapi } \\
\text { dengan tali pengikat. Layo } \\
\text { biasanya ditempatkan pada bagian } \\
\text { perut penuai padi yang talinya } \\
\text { diikatkan ke belakang. Biasanya, } \\
\text { padi yang ditempatkan ke dalam } \\
\text { wadah layo adalah padi yang } \\
\text { tangkainya kecil dan pendek } \\
\text { sehingga sukar untuk diikat. }\end{array}$ & $\begin{array}{l}\text { Sebagai wadah/tempat } \\
\text { untuk menyimpan } \\
\text { padi yang telah dituai }\end{array}$ & $\begin{array}{l}\text { Alat ini digunakan } \\
\text { oleh tenaga } \\
\text { perempuan. }\end{array}$ \\
\hline 5. & $\begin{array}{l}\text { Gampiri adalah tempat } \\
\text { penyimpanan padi, berbentuk } \\
\text { rumah kecil, dibuat dari kayu, } \\
\text { bambu, pelepah sagu, dan atap } \\
\text { dari daun rumbia. Gampiri } \\
\text { biasanya ditempatkan di } \\
\text { tempatkan di samping rumah } \\
\text { tinggal. Ikatan-ikatan padi dari } \\
\text { sawah disusun di dalamnya } \\
\text { sebelum proses lebih lanjut } \\
\text { menjadi beras. }\end{array}$ & $\begin{array}{l}\text { Sebagai tempat } \\
\text { penyimpanan padi. }\end{array}$ & $\begin{array}{l}\text { Orang yang } \\
\text { menyimpan padi } \\
\text { dalam gampiri } \\
\text { bisa laki-laki } \\
\text { maupun } \\
\text { perempuan. }\end{array}$ \\
\hline 6. & $\begin{array}{l}\text { Horenggo (sabit) adalah alat } \\
\text { pemotong batang padi yang } \\
\text { terbuat dari besi berbentuk } \\
\text { bengkok/melengkung yang } \\
\text { matanya cukup tajam dan diberi } \\
\text { hulu dari kayu. }\end{array}$ & $\begin{array}{l}\text { Untuk memotong } \\
\text { batang padi }\end{array}$ & $\begin{array}{l}\text { Alat ini dapat } \\
\text { digunakan oleh } \\
\text { laki-laki maupun } \\
\text { perempuan, dewasa } \\
\text { maupun anak-anak }\end{array}$ \\
\hline 7. & $\begin{array}{l}\text { Dopi poboba adalah alat yang } \\
\text { terbuat dari kayu papan yang }\end{array}$ & $\begin{array}{l}\text { Sebagi alat untuk } \\
\text { merontokkan atau }\end{array}$ & $\begin{array}{l}\text { Alat ini dapat } \\
\text { digunakan oleh }\end{array}$ \\
\hline
\end{tabular}




\begin{tabular}{|c|l|l|l|}
\hline & $\begin{array}{l}\text { diatur dengan posisi agak miring } \\
\text { dan disandarkan pada kedua kaki. } \\
\text { Alat ini terbuat dari kayu atau } \\
\text { bambu. Cara pemakaiannya, } \\
\text { batang padi dipukulkan di atas } \\
\text { dopi poboba sampai butir-butir } \\
\text { padi secara keseluruhan terlepas } \\
\text { dari tangkainya. }\end{array}$ & $\begin{array}{l}\text { memisahkan butir- } \\
\text { butir padi dari } \\
\text { tangkainya. }\end{array}$ & $\begin{array}{l}\text { laki-laki maupun } \\
\text { perempuan, dewasa } \\
\text { maupun anak-anak }\end{array}$ \\
\hline 8. & $\begin{array}{l}\text { Ompa adalah bentangan daun } \\
\text { silar, karung, tikar, atau kain yang } \\
\text { berfungsi untuk memudahkan } \\
\text { dalam pengumpulan butir-butir } \\
\text { padi. }\end{array}$ & $\begin{array}{l}\text { Sebagai wadah } \\
\text { penampung butir-bitir } \\
\text { padi. }\end{array}$ & $\begin{array}{l}\text { Alat ini dapat } \\
\text { digunakan oleh } \\
\text { laki-laki maupun } \\
\text { perempuan, dewasa } \\
\text { maupun anak-anak }\end{array}$ \\
\hline 9. & $\begin{array}{l}\text { Tapi adalah alat yang dipakai } \\
\text { untuk membersihkan padi dari } \\
\text { kotoran-kotoran atau butiran- } \\
\text { butiran padi yang rusak atau } \\
\text { kosong (hampa). Alat ini dibuat } \\
\text { dari anyaman bambu, berbentuk } \\
\text { lingkaran dengan pinggir } \\
\text { berbingkai. }\end{array}$ & $\begin{array}{l}\text { Untuk membersihkan } \\
\text { kotoran-kotoran yang } \\
\text { masih bercampur } \\
\text { dengan gabah. }\end{array}$ & $\begin{array}{l}\text { digunakan oleh } \\
\text { laki-laki maupun } \\
\text { perempuan }\end{array}$ \\
\hline
\end{tabular}

\subsection{Pengolahan Hasil}

Ada beberapa alat produksi tradisional yang dapat digunakan dalam pengolahan hasil pertanian sawah ini, yaitu

(1) nonju patahuda, (2) alu, dan

(3)

nonjupompeohe

Tabel 5: Pengolahan Hasil

\begin{tabular}{|c|l|l|l|}
\hline No. & \multicolumn{1}{|c|}{ Nama Alat dan Artinya } & \multicolumn{1}{c|}{ Fungsi/Kegunaan } & \multicolumn{1}{c|}{ Keterangan } \\
\hline 1. & $\begin{array}{l}\text { Nonju patahuda (lesung) adalah } \\
\text { alat yang terbuat dari kayu yang } \\
\text { ukurannya cukup besar, yakni } \\
1-2 \text { meter, diberi lubang secara } \\
\text { memanjang. Ikatan padi yang } \\
\text { masih dengan tangkainya } \\
\text { diletakkan dalam lubang } \text { nonju } \\
\text { patahuda kemudian ditumbuk } \\
\text { dengan alu. }\end{array}$ & $\begin{array}{l}\text { Untuk memisahkan } \\
\text { butir padi dari tangkai } \\
\text { atau batangnya. }\end{array}$ & $\begin{array}{l}\text { Alat ini dapat } \\
\text { digunakan oleh } \\
\text { perempuan. }\end{array}$ \\
\hline 2. & $\begin{array}{l}\text { Alu adalah alat yang terbuat dari } \\
\text { batang kayu yang dibentuk } \\
\text { mengecil bagian tengahnya untuk } \\
\text { pegangan dan kedua ujungnya } \\
\text { tumpul. }\end{array}$ & $\begin{array}{l}\text { Untuk menumbuk } \\
\text { padi (memisahkan } \\
\text { dari tangkai dan } \\
\text { batang) }\end{array}$ & $\begin{array}{l}\text { Alat ini dapat } \\
\text { digunakan oleh } \\
\text { perempuan. }\end{array}$ \\
\hline 3. & $\begin{array}{l}\text { Nonjupompeohe adalah alat yang } \\
\text { digunakan untuk memproses butir } \\
\text { padi menjadi beras. Alat ini } \\
\text { terbuat dari kayu yang dilubangi } \\
\text { bundar yang cukup dalam. Butir }\end{array}$ & $\begin{array}{l}\text { Untuk menumbuk } \\
\text { padi (sampai menjadi } \\
\text { beras) }\end{array}$ & $\begin{array}{l}\text { Alat ini dapat } \\
\text { digunakan oleh } \\
\text { perempuan. }\end{array}$ \\
\hline
\end{tabular}




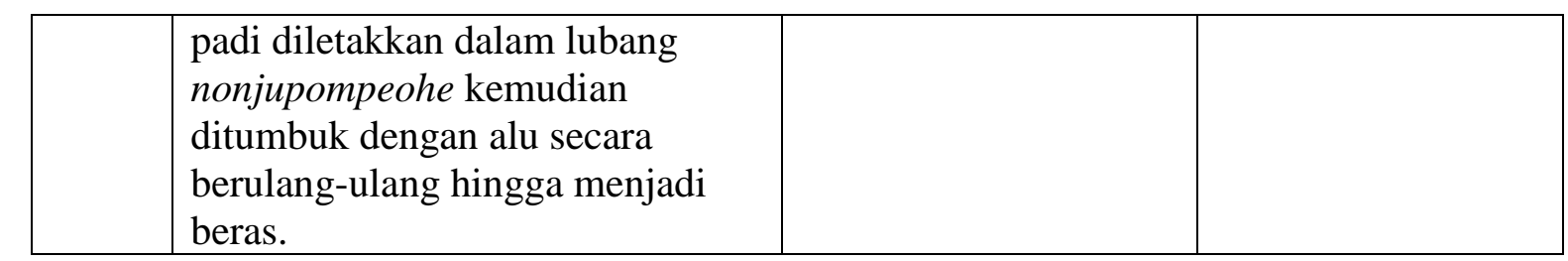

5. Simpulan

Dari hasil penelitian terhadap makna leksikal peralatan tradisional produksi bidang pertanian sawah bagi masyarakat Kaili di Sulawesi Tengah dapat disimpulkan bahwa secara garis besar, terdapat lima jenis alat tradisional produksi pertanian masyarakat Kaili di Sulawesi Tengah, yaitu:

(a) alat pengolahan tanah yang memiliki tiga nama alat tradisional, yaitu: salaga, pompoe, dan pomanggi;

(b) alat penanaman yang memiliki tiga nama alat tradisional, yaitu: pohudu, bingga atau rombe, dan polemba;

(c) alat pemeliharaan tanaman yang memiliki sembilan nama alat tradisional, yaitu: pomanggi, taono, harenggo, popuji, pohive, pandole, huwa, kate, dan povante;

(d) alat pemungutan hasil yang memiliki sembilan nama alat tradisional, yaitu: pula, kato,tali, layo/tonda,gampiri, harenggo, dopi poboba, ompa, dan tapi; dan

(5) pengolahan hasil yang memiliki tiga nama alat tradisional, yaitu: nonju patahuda, alu, dan nonjupompeohe.

\section{Daftar Pustaka}

Aminudin. (2001). Semantik Pengantar Studi tentang Makna. Bandung: Sinar Baru Algesindo.

Arifin, E. Zaenal dan S. Amran Tasai. (2010). Cermat Berbahasa Indonesia untuk Perguruan Tinggi. Sebagai Mata Kuliah Pengembangan Kepribadian (MPK): Akademika Pressindo.

Chaer, Abdul. (2010). Leksikologi \& Leksikografi Indonesia. Jakarta: Rineka Cipta.

Djajasudarma, T.F. (1999). Semantik 1 Pengantar ke Arah Ilmu Makna. Bandung: Refika Aditama.

Herawati, Isni dan Sumintarsih. (1989). Peralatan Produksi Tradisional dan Perkembangannya di Daerah Istimewa Yogyakarta. Yogyakarta: Departemen Pendidikan dan Kebudayaan.

Kridalaksana, Harimurti. (2001). Kamus Linguistik. Edisi Ketiga. Jakarta: Gramedia Pustaka Utama.

Pateda, Mansoer. (1989). Semantik Leksikal. Ende: Nusa Indah.

Pitojo, Setijo. (2000). Budi Daya Padi Sawah Tabela. Jakarta: Penebar Swadaya.

Parera, Jos D. (2004). Teori Semantik. Jakarta: Erlangga.

Wijana, I Dewa P. \& Rohmadi, Muhammad. (2008). Semantik; 
Teori dan Analisis. Surakarta: Yuma Pustaka.

Sudaryanto. (1998). Metode Linguistik. Bag. 2: Ke Arah Memahami Metode Linguistik. Yogyakarta: Gadjah Mada University Press.

Sukandarrumidi. (2006). Metodologi Penelitian: Petunjuk Praktis untuk
Peneliti Pemula. Yogyakarta: Gadjah Mada University Press.

Tim Penyusun Kamus Pusat Bahasa. (2008). Kamus Besar Bahasa Indonesia. Jakarta: Balai Pustaka.

Verhaar, J. W. M. (2012). Asas-Asas Linguistik Umum. Yogyakarta: Gajah Mada University Press. 